Journal of MMIJ Vol.131 p.602- 609 (2015)

C 2015 The Mining and Materials Processing Institute of Japan

総 説

Review

\title{
日本におけるマンガン団塊探査の現状 *
}

\section{津 根 明 ${ }^{1}$ 岡 崎 正 次 ${ }^{2}$}

\section{Current Situation of Manganese Nodule Exploration in Japanese License Area}

\author{
by Akira TSUNE ${ }^{\mathrm{a}^{*}}$ and Masatsugu OKAZAKI ${ }^{\mathrm{a}}$
}

a. Deep Ocean Resources Development, Co., Ltd. 1-3-15 Nihonbashi-Horidome-Cho, Chuoh-Ku, Tokyo, 103-0012, Japan (*Corresponding author, E-mail: tsune@dord.co.jp)

Exploration survey cruise of manganese nodule in the Clarion-Clipperton Zone (CCZ) has been conducted by DOMA (Deep Ocean Minerals Association) and DORD (Deep Ocean Resources Development Co., Ltd.) from 1975 to 1996 and 2011 to present. The manganese nodule survey of Japan in the CCZ during these periods is reviewed in this paper. From 1975 to 1987, the surveys were conducted in a wide area of the CCZ (3 million $\left.\mathrm{km}^{2}\right)$ in order to find and extract high potential areas of manganese nodules. After the registration of the Japanese license area $\left(75,000 \mathrm{~km}^{2}\right.$, consisting of West Area and East Area) in 1987, the aims of the surveys were shifted toward building up exploration techniques during 1987 to 1996, rather than extraction of high potential area. From 2011, exploration works were carried out in a selected area of the High Abundance Area (HAA), located in northwest of the West Area, for the purpose of increasing accuracy of manganese nodule resources by additional sampling, seafloor observation with taking photographs and acoustic sounding survey. Most of the area of the HAA, which is selected as a possible first target for commercial mining of Japan in future, is covered by the area of high nodule abundance of more than $10 \mathrm{~kg} / \mathrm{m}^{2}$. For the survey of 2012 in the HAA, AUV (Autonomous Underwater Vehicle) equipped with MBES, SBP, SSS and deep seas camera was used. Exploration equipment of modern technology such as AUV plays indispensable role in deep sea survey, and it is highly important to keep up with updated technologies for increasing quality of the surveys. Furthermore, the selection of model area(s) and the determination of the priority of survey contents are necessary for the preparation of the future survey plan.

KEY WORDS: Deep-Sea Mineral Resources, Manganese (polymetallic) Nodule, Contract for Exploration, Exploration Cruises and International Seabed Authority

\section{1.はじめに}

深海底に分布するマンガン団塊は, 1960 年代以降から新たな 鉱物資源として注目され，先進諸国によって探査・開発が進めら れてきた。日本においても 1970 年代から洋上調査が本格化し, 旧地質調查所・旧公害資源研究所による学術的な調查航海と旧通 商産業省資源エネルギー庁による探查航海 ( 旧金属鉱業事業団に 委託) が開始された。探査活動は八ワイ南東のクラリオン・クリッ パートン断裂帯 (Clarion-Clipperton Fracture Zone ; CCZ) から有望 な海域を絞り込むために行われ，旧金属鉱業事業団から再委託を 受けた深海底鉱物資源開発協会 (DOMA) によって 1975 年から行 われた。1982 年には官民出資により設立された深海資源開発株 式会社 (DORD) が DOMA の洋上調査を引き継ぎ, 1983 年からは 委託調查の他に DORD 独自の予算による洋上調査 (自主調查) も

*2014 年 4 月 16 日受付 2014 年 7 月 25 日受理

1. 深海資源開発株式会社 資源調査部 主任技師

2. 正会員 深海資源開発株式会社 資源調査部 主席技師長

[ 著者連絡先 ] FAX: 03-3664-1930 E-mail: tsune@dord.co.jp

キーワード : 深海底鉱物資源, マンガン団塊, 探査契約, 探査航海, 国際 海底機構
委託調査と平行して行った ${ }^{1)}$ 。1987 年には DORD は CCZ の八 ワイ南東沖の位置にマンガン団塊の有望鉱区を登録し, 排他的な 探査権を獲得し, 1996 年まで洋上調査を継続した。

これと平行して, 開発に必要となる採鉣技術 ${ }^{2)}$ や製錬技術 ${ }^{3)}$, 環境調查 ${ }^{4)}$ 等についても様々な取り組みが行われたが ${ }^{5)}$, 特に 採鉱技術については, 旧通商産業省工業技術院の大型工業技術研 究開発制度による「マンガン団塊採鉱システムの研究開発」が進 められ, 水深 2,200 m での採鉱実証試験等が行われ, 1997 年に終 了した ${ }^{2)}$ 。

2000 年 7 月に国際海底機構 (ISA; International Seabed Authority) において探查規則「深海底における多金属性団塊の概要調查及び 探查に関する規則」が採択されたことを受け, DORD は2001 年 6月にISA との間で既保有鉱区に関する探查権の契約を締結した。 その後 DORD は契約に基づき, それまでの洋上調查結果の解析 や関連技術調查等を進めたが, さらに資源量評価, 採鉱システム の検討に必要な精度の情報を得る等のため, 2011 年から新たな 調査機器も導入して洋上調査を再開した。

そこで, 本稿で執筆する機会を借りDOMA および DORD が実施した $1975 〜 1996$ 年の洋上調查と, 近年実施している $2011 \cdot 2012$ 年の洋上調查の目的・手法, その変遷についてまとめ 
Table 1 List of navigation systems, samplers and the other survey instruments utilized for DORD exploration cruises for manganese nodule.

（1）測位システム

\begin{tabular}{|c|c|c|}
\hline 人工衛星測位装置 & \multirow{2}{*}{ 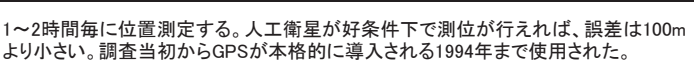 } & \multirow{2}{*}{ - } \\
\hline NNSS (Navy Navigation Satellite System) & & \\
\hline 全地球測位システム & \multirow{2}{*}{$\begin{array}{l}\text { 人工衛星を利用した濉位システム。1998年時点で1日22時間以上の使用可能。相対 } \\
\text { 精度は } 10^{-6} \sim 10^{-7} か ゙ \text { 期待でき、また絶対精度も10数m程度まで可能である。 }\end{array}$} & \multirow{2}{*}{ - } \\
\hline GPS (Global Positioning System) & & \\
\hline トランスポンダー航法システム & \multirow{2}{*}{ 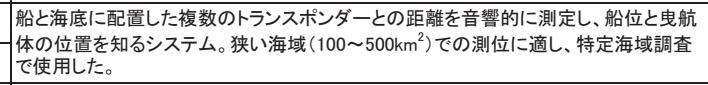 } & \multirow{2}{*}{ - } \\
\hline TPS (TransPonder navigation System) & & \\
\hline 水中音響測位装置 & \multirow{2}{*}{ 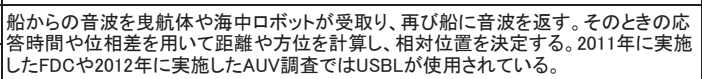 } & \multirow{2}{*}{ - } \\
\hline USBL (Ultra Short Base Line) & & \\
\hline
\end{tabular}

(2) サンプリング機器

\begin{tabular}{|c|c|c|}
\hline フリーフォールグラブ & \multirow{2}{*}{ 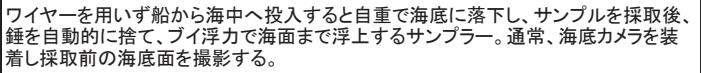 } & \multirow{2}{*}{$\begin{array}{c}\text { 試料採取 } \\
\text { (マンガン団塊) }\end{array}$} \\
\hline FG (Freefall Grab) & & \\
\hline スペードコアラー(ボックスコアラー) & \multirow{2}{*}{ 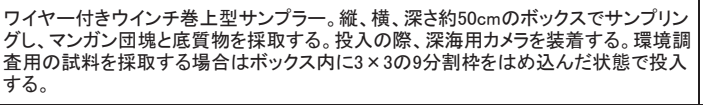 } & \multirow{2}{*}{$\begin{array}{c}\text { 試料採取 } \\
\text { (マンガン団塊と底質物) }\end{array}$} \\
\hline SC (Spade-type box Corer) & & \\
\hline ピストンコアラー & \multirow{2}{*}{$\begin{array}{l}\text { ワイヤー付きウインチ巻上型の底質物サンプラー。着底するとコアチューブは堆積物 } \\
\text { に貫入する。最長 } 12 \mathrm{~m} \text { 堆積物を採取できる。 }\end{array}$} & \multirow{2}{*}{$\begin{array}{l}\text { 試料採取 } \\
\text { (底質物) }\end{array}$} \\
\hline PC (Piston Corer) & & \\
\hline 大ロ径コアラー & \multirow{2}{*}{$\begin{array}{l}\text { ワイヤー付きウインチ巻上型底質物サンプラー。約4 6m長のサンプラーで柱状の底 } \\
\text { 質物試料を採取する。採泥管の上端部には底質物の逸失を防ぐコアキャツチャー } \\
\text { が装着されている。深海用カメラを装着。 }\end{array}$} & \multirow{2}{*}{$\begin{array}{l}\text { 試料採取 } \\
\text { (底質物) }\end{array}$} \\
\hline LC (Large Corer) & & \\
\hline マンガンドレッジ & \multirow{2}{*}{ 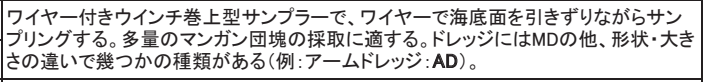 } & \multirow{2}{*}{$\begin{array}{l}\text { 試料採取 } \\
\text { (大量のマン゙ガン団塊採 } \\
\text { 取) }\end{array}$} \\
\hline MD (Manganese nodule dredge) & & \\
\hline マルチプルコアラー & \multirow{2}{*}{$\begin{array}{l}\text { ワイヤー付きウインチ巻上型サンプラ一。環境調査のための底質物不擋乱試料を採 } \\
\text { 取する。脱着可能な8本のコアが中心部に着装されている構造である。深海用カメラを } \\
\text { 装着。 }\end{array}$} & \multirow{2}{*}{$\begin{array}{l}\text { 試料採取 } \\
\text { (底質物; 環境調査) }\end{array}$} \\
\hline MC (Multiple Corer) & & \\
\hline ロゼットサンプラー & \multirow{2}{*}{ 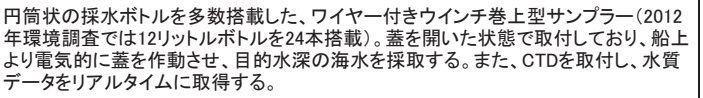 } & \multirow{2}{*}{$\begin{array}{l}\text { 水質調査 } \\
\text { (環境調) }\end{array}$} \\
\hline RO (Rosette sampler) & & \\
\hline
\end{tabular}

\section{(3) 海底観察など}

\begin{tabular}{|c|c|c|}
\hline 深海テレビ & \multirow{2}{*}{ 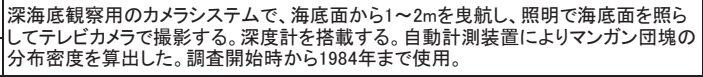 } & \multirow{2}{*}{ 海底観察 } \\
\hline DTV (Deepsea TV) & & \\
\hline 連続深海カメラ & \multirow{2}{*}{ 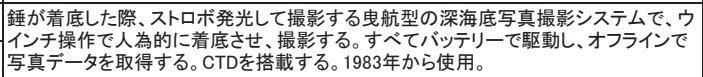 } & \multirow{2}{*}{ 海底観察 } \\
\hline $\begin{array}{l}\text { CDC (Continuous Deepsea Camera) } \\
\text {. }\end{array}$ & & \\
\hline ファインダー付き深海カメラ & \multirow{2}{*}{ 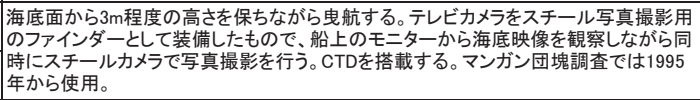 } & \multirow{2}{*}{ 海底観察 } \\
\hline FDC (Finder-installed Deepsea Camera) & & \\
\hline 電気伝導度 $\cdot$ 水温 -水深測定装置 & \multirow{2}{*}{$\begin{array}{l}\text { 海水の電気伝導度、水温、水圧を同時に測定できる計測器。これにより海水の塩分 } \\
\text { 濃度、水深、密度及び中水中音速(MBESデータ用)が算出される。単独で投入するこど } \\
\text { もあるが、ROやFDCなどに取付する。 }\end{array}$} & \multirow{2}{*}{$\begin{array}{l}\text { 水質調査 } \\
\text { (環境調査) }\end{array}$} \\
\hline CTD (Conductivity Temperature Depth profiler) & & \\
\hline
\end{tabular}

\section{(4) 音響調查(地形調査など)}

\begin{tabular}{|c|c|c|}
\hline ナロービーム音響測深機 & \multirow{2}{*}{$\begin{array}{l}\text { 30kHzの音波を用いた音響測深機。周波数が高いので、指向角が高く精度の高い測 } \\
\text { 定が可能である。調查当初の水深はNBSで測定していた。 }\end{array}$} & \multirow{2}{*}{ 地形調査 } \\
\hline NBS (Narrow Beam echo Sounder) & & \\
\hline マルチビーム音響測深機 & \multirow{2}{*}{$\begin{array}{l}\text { 船底から指向角の小さい音波(15.5kHz)を扇状に発射し、水深の2倍の幅の海底地形 } \\
\text { をリアルタイム゙描くことが出来る。1991年に導入後、鉱区全域を走り、20mコンター } \\
\text { の地形図を作成した。 }\end{array}$} & \multirow{2}{*}{ 地形調査 } \\
\hline MBES (Multi-narrow Beam Echo Sounder) & & \\
\hline サブボトムプロファイラー(表層断面探査装置) & \multirow{2}{*}{\begin{tabular}{|l} 
船底から周波数の低い(3.5kHz)音波を出し、反射波を受信することにより海底表層部 \\
の断面データを表示し収録する。
\end{tabular}} & \multirow{2}{*}{ 地形調査 } \\
\hline SBP (Sub Bottom Profiler) & & \\
\hline ナロービームサブボトムプロファイラー & \multirow{2}{*}{$\begin{array}{l}\text { n-SBPでは周波数の違う2つの音波を発振し、その周波数差から指向角の狭い } \\
\text { 3.5kHzを作り出す。このことによ解像度の高い(比較的浅部の)海底表層部のデータ } \\
\text { を取得出来る。 }\end{array}$} & \multirow{2}{*}{ 地形調査 } \\
\hline n-SBP (narrow-Sub Bottom Profiler) & & \\
\hline 精密音響測深機 & \multirow{2}{*}{$\begin{array}{l}\text { 12kHzの音波を用いた音響測深機。ピンガー(曳航体の海底面からの高さ測定器)に } \\
\text { も利用する。 }\end{array}$} & \multirow{2}{*}{ 地形調査 } \\
\hline PDR (Precision Depth Recorder) & & \\
\hline 多周波数超音波探査装置 & \multirow{2}{*}{ 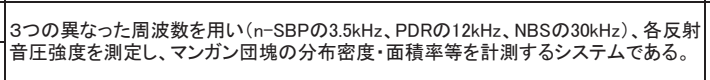 } & \multirow{2}{*}{ 資源調査 } \\
\hline MFES (Multi-Frequency Exploration System) & & \\
\hline サイドスキャンソナー & \multirow{2}{*}{ 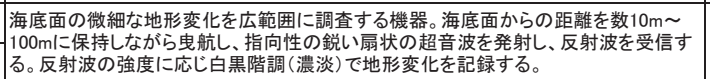 } & \multirow{2}{*}{ 地形調査 } \\
\hline SSS (Side Scan Sonar) & & \\
\hline
\end{tabular}

(5) 水中ロボット

\begin{tabular}{|c|c|c|}
\hline 自律型無人潜水機 & 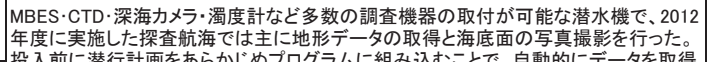 & 地形調査 \\
\hline AUV (Autonomous Underwater Vehicle) & 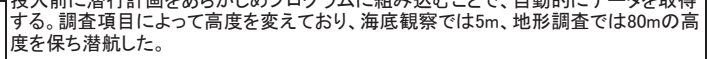 & 海底観察 \\
\hline
\end{tabular}

マンガン団塊調査報告書 (4次概査のまとめ) (DORD非公表資料、1998年)からの引用及び一部加筆·修正。 


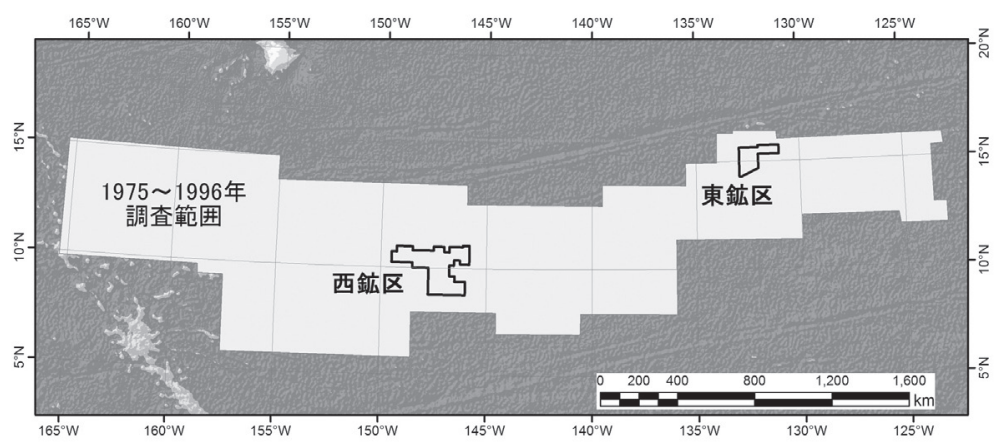

Fig.1 Location map of the survey area for Japanese exploration cruises mostly as pioneer investor in the Clarion-Clipperton Fracture Zone $\left(3\right.$ million $\left.\mathrm{km}^{2}\right)$. The black frames indicate Japanese license areas, $75,000 \mathrm{~km}^{2}$, consisting of West Area and East Area. The wet resources of both of the West and East Area were calculated to be 513 million tons and 170 million tons, respectively.

た。洋上調査の歴史は新規調查機器の使用・調査技術の進歩と ともにあり, 数 10 年の間に数多くの調査機器を用いた。主な調 查機器を Table 1 にまとめ, 本稿では表に記す略語を使用する。 1996 年以前の調査経緯や調査船, 調査内容や各国の動向等につ いては寸でに幾つか総説・解説が公表されており 1,6,8-11)，特に 松本ら ${ }^{6)}$ では 1996 年以前の DOMA 及び DORD の洋上調査の調 查方法・結果については述べられているため, 本稿ではなる心゙く 重複を避けるよう留意した。2011・2012 年には環境調査で底質 物のサンプリングや水質調查などを実施しているが 7)，本稿で は詳細は述べず, 調査機器や調査数など簡単に触れるに留めた。 また, DORD は現在, 探査契約が終了する 2016 年までにマンガ ン団塊開発の経済性を再評価す心゙く, 洋上調査の他に, 採鉱及び 製鍊システムに関する動向調查・机上検討等を行っているが 7), 本稿では特に洋上調査の内容に限って述べる。なお, ISAの公式 文書では polymetallic nodule (多金属性団塊) という用語が使用さ れているが, 本文ではなじみのある “マンガン団塊”を使用する。

\section{2. $1975 \sim 1996$ 年の探査航海}

\section{$2 \cdot 1$ 調査地域}

調査地域である太平洋のハワイ東南方沖の CCZ は世界で最も 広範囲にマンガン団塊が分布している海域として知られている。 同地域の水深は 4,000 6,000 $\mathrm{m}$ で東から西に向かって深くな り, 東部でほぼ $5,000 \mathrm{~m}$ 以浅で, 西部ではほぼ $5,000 \mathrm{~m}$ 以深であ る ${ }^{12)}$ 。CCZ はニッケル, コバルト, 銅の合計品位が約 $2.5 \%$ 以 上のマンガン団塊が密に分布しており, 米国, 旧西ドイツ等の先 進国の大企業により1960 年代から 1970 年代にかけて積極的な探 查が行われた。現在では, CCZ 内に日本を含め 11 の国ないしは 団体が ISA から探查権を取得し探査活動を行っている (2013 年 5 月現在）。先に述べたように DOMA および DORD は CCZ の幅 約 $500 \sim 1,000 \mathrm{~km}$, 東西方向約 $4,600 \mathrm{~km}\left(165 \sim 123^{\circ} \mathrm{W}\right)$ の約 300 万 $\mathrm{km}^{2}$ の範囲 (Fig. 1) において 1) 賦存状況の概要把握, 2) 有望 地域の選定を行い, そして 1987 年に排他的探査権を申請した後 は，3）同鉱区の資源量を推定するために洋上調査を実施した。

\section{$2 \cdot 2$ 調査概要}

有望地域の選定や概略資源量の把握のためには広範囲にわたる マンガン団塊の品位や分布状況 (分布密度; 単位は $\mathrm{kg} / \mathrm{m}^{2}$ ) のデー 夕を蓄積する必要がある。品位は経済的に注目している金属元素 ( $\mathrm{Co}, \mathrm{Ni}, \mathrm{Cu}$ など) の含有量で, サンプリングしたマンガン団塊 の化学分析によって得られる。調查船には蛍光 X線分析装置が設 置されており, 船上で分析值を求めた。また分布密度は $\mathrm{FG} \cdot \mathrm{SC}$ によるサンプリング ( 直接的調査) だけでなく, 海底観察 (やや
広域・間接的調査), 音響調査 (広域・間接的調査) によって推 定された。

調查航海は 1975 年から 1996 年まで毎年行われ，1975～1979 年は「白嶺丸」 ${ }^{10,13)}, 1980 \sim 1996$ 年は「第 2 白嶺丸」 ${ }^{6)}$ を調査 船として使用した。これらの調查船は (マンガン団塊委託調查・ 自主調査合わせて ) 年間約 70 日から最大で 290 日程度運航した。 なお基本的には 1 航海 (Leg) は 30 日前後で計画され, ホノルル 一調査海域の往復に合計 $6 \sim 12$ 日程度要するので, 実質的に調 查日数は Leg 毎に 20 日前後となる。

以下に調查項目毎に使用した機器とその調査内容について概説 する。

\section{$2 \cdot 3$ 調査結果}

(1) 地形調査海底地形調査は $12 \mathrm{kHz}$ PDR (1975 1979 年) および 30kHz NBS (1980〜 1990 年) により実施し, サンプリン グ地点間を移動する間に測定し, 等深線間隔が $200 \mathrm{~m}$ の海底地 形図を作成した。なお, PDR, NBS はいずれも直下測深による 方法である。1 991 年からは $15.5 \mathrm{kHz}$ MBES を導入し, 船の左右 方向に幅広い (下に 90 度の範囲に) 音波を出し, 多数の受波器 で受信することにより, 広範囲を一度に測深することが可能に なった。そして 1996 年までに取得鉱区内において等深線間隔が $20 \mathrm{~m}$ の海底地形図を作成した。なお, 調査当初の測位システムは NNSS ${ }^{14)}$ であったが，1986 年に GPS が導入された。

表層堆積物調查は PDR や NBS に比べて低い周波数の $3.5 \mathrm{kHz}$ SBP および nSBP を使用し, 海底地形調査同様, サンプリング地 点間を航走中に測定した。SBPの記録紙には海底地形と海面下の 地層が濃淡で示されており (不透明層・透明層と呼ばれる), こ の濃淡のパターンで表層堆積物を分類した。そして, 底質物の音 波反射特性と地質的特徵との関連をみるため, PC などの柱状サ ンプラーで底質物を採取した。

（2）地質調査（サンプリング）サンプリングは採取内容に より次の 4 つ方法に分類される：1）マンガン団塊を採取する 方法 (主に FG を使用)，2）マンガン団塊と底質物とを不摚乱状 態で採取する方法 (SC を使用)，3）底質物の柱状試料を採取する 方法 (PC やLC を使用) , 4) 大量のマンガン団塊を採取するドレッ ジによる方法 (MD などを使用)。サンプリング後の処理につい ては松本ら ${ }^{6)}$ に詳しいので詳細は割愛するが, マンガン団塊に 対してはサイズ区分, 形態記載, 切断面記載等を, 底質物に対し ては底質物記載や物性試験等を実施した。その後, 品位分析や X 線回折試験等の室内試験に供する試料準備を行った ${ }^{6)}$ 。さらに サンプリング機器に取り付けた海底カメラで着底直前の海底写真 を撮影し, 各写真に対し画像処理を行った (後述)。 


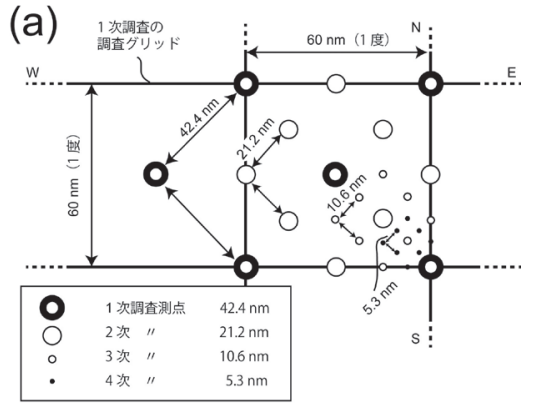

(b)

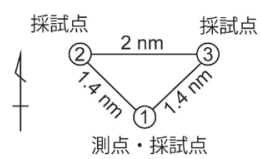

Fig.2 Schematic illustrations showing strategies for locations of sampling points. (a) Standard grids for surveys and intervals of sampling points for each survey stage. (b) three sampling locations for each sampling point.

処理後のデータは, 有望地域の絞り込みを行うために整理・活 用した。マンガン団塊の地質的情報を地域間で比較するために 調查海域を大きく西部海域, 中央海域, 東部海域の 3 つに区切 り ${ }^{6)}$ ，さらにそれぞれの区域を小分割し，地域毎の特徴を整理 した。その他, 例えばマンガン団塊の分布密度と海底静止画像に おけるマンガン団塊の被覆面積率との関係や, 音響装置による反 射音圧と分布密度の関係など探査技術・手法の向上のためにデー タを整理した。

(3) 地質調査 (海底観察) 深海カメラによる海底観察調査 (DTV，CDC，FDCを使用）は，マンガン団塊の賦存状況および その連続性を確認するためのデータを迅速に収集するために実施 した。海底観察には分布密度自動計測システム, カラー映像やス テレオ撮影等, 様々な技術が導入されたが, 基本的な調查プロセ スとしては, 得られた映像・写真データから画像処理でマンガン 団塊の面積率, 粒径, 単位面積当たりの個数を求め, 分布密度を 計算するという順序で行った。実際のマンガン団塊は底質物上に ある程度埋没しているため, 画像処理から得られる分布密度は実 測值と差が出てくる。そのため, 揚収したマンガン団塊から得ら れた情報と, 深海カメラの海底画像から得られた情報とを比較す ることにより, 最終的には画像データから分布密度をより正確に 推定するための経験式を得た。

(4) 有望地域の絞り込みと特定海域調査調查当初は緯度・ 経度ともに $1^{\circ}(60 \mathrm{~nm} ; 1 \mathrm{~nm}=1.852 \mathrm{~km})$ の方眼を基線とした図面 を用い, 測点間隔は Fig. 2aに示すように, 緯度・経度それぞれ $1^{\circ}$ の交点と方眼の中心点との間の距離を $42.4 \mathrm{~nm}$ とした (1 次調 查)。データをコンパイルしつつ次段階のサンプリング候補地を 定め, 2 次調查では 1 次調查の中点を埋めるように測点を追加し, $42.4 \mathrm{~nm}$ の半分の $21.2 \mathrm{~nm}$ を測点間隔とした。以下同様に 3 次調 查 $10.6 \mathrm{~nm}, 4$ 次調査 $5.3 \mathrm{~nm}$ とし, 有望地域を絞り込むべくサン プリングを行った。各測点におけるサンプリングは複数回行い (その多くは Fig. $2 b$ に示すように二等辺三角形の形になるような 場所で 3 回行った), 資源量の計算の際にはそれらの採試点デー タの平均值を各測点のデータとして用いた。そして高品位, 高分 布密度地域を探しながら調查範囲を 300 万 $\mathrm{km}^{2}$ から約 8 万 $\mathrm{km}^{2}$ まで絞り込んだ。

有望地域における調査は 1983 年以降, 委託調査とは別に自主 調查でも開始された。そして 1987 年には Fig. 1 に示す 2 箇所 (西 鉱区と東鉱区) 約 $75,000 \mathrm{~km}^{2}$ で探查鉱区を取得し, 1987 年以降

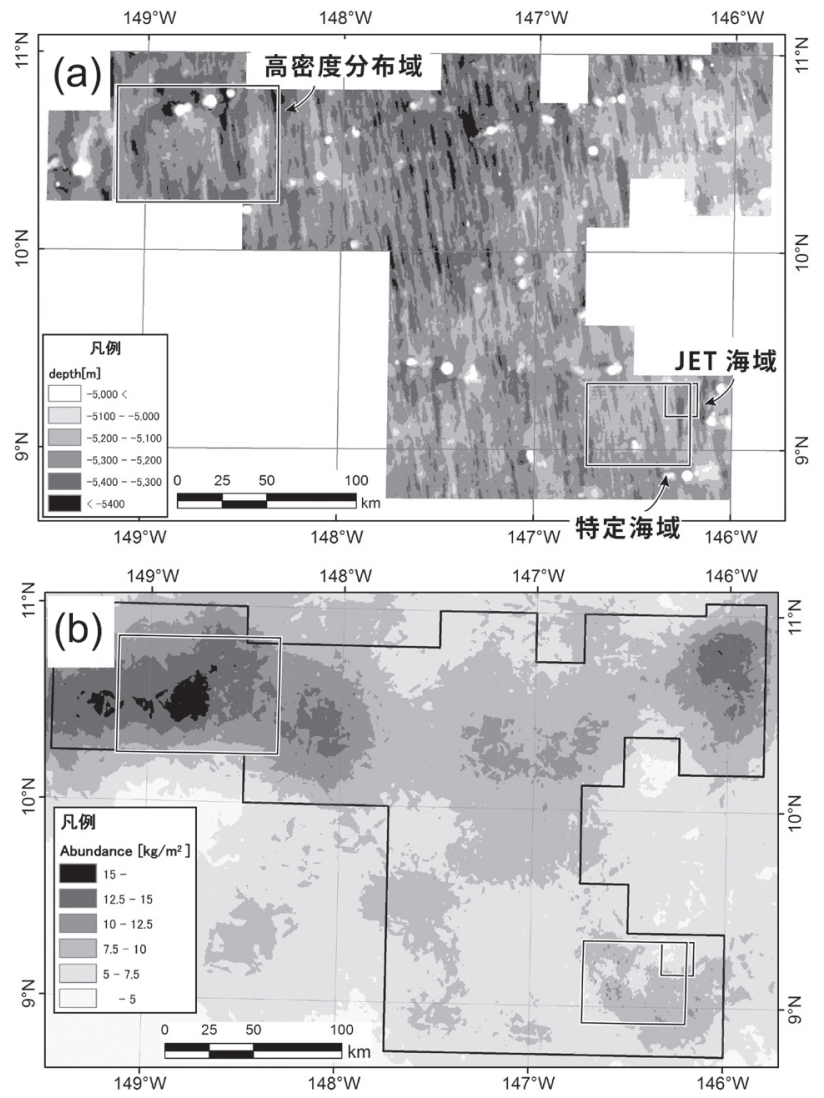

Fig.3 West Area of Japanese license areas. (a) bathymetry map and (b) abundance distribution map. A northwest rectangle: High Abundance Area, A southeast rectangle: Selected area for developing exploration techniques. A southeast small rectangle: JET Area for environmental survey (JET: Japan Deep-Sea Impact Experiment) .

の調査は委託調査・自主調査ともに鉱区内に限定して行った。

鉱区登録以降は探査航海の目的を探査技術 (鉱床評価手法及 び精查方法等) の確立に移行し, 1989 年以降は特定海域と呼 ばれるやや狭い範囲で集中的に調查を行った。特定海域は緯度 $8^{\circ} 55^{\prime} \sim 9^{\circ} 20^{\prime} \mathrm{N}$, 経度 $146^{\circ} 12^{\prime} \sim 146^{\circ} 44^{\prime} \mathrm{W}$ (約 $2,700 \mathrm{~km}^{2}$ ) の範 囲で，1989 年以降環境調査を実施しているJET 海域 ${ }^{4)}$ を含む (Fig. 3a)。特定海域では 1) GPS ・ MBES の地形位置精度を把握す る調查, 2) 深海カメラによる連続的な ( $80 \mathrm{~m}$ 間隔) 海底写真撮影, さらに, より効率的にマンガン団塊の分布状況を知るための技術 として，3）地形調查で使用寸る音響測深技術を用いて, 海底反 射音圧の強度とマンガン団塊の分布密度の関係を調查した。

\section{$2 \cdot 2$ 課題}

概査終了後の地形図の精度は, 地形概略の把握には十分であ る。しかし地形と分布密度の関係を把握寸ることや, 採鉱可能領 域 (採鉱機のオペレーションが可能な平坦地や緩斜面) や障害物 の判定, そして最適な集鉱システムを考える上ではまだ十分では ない。調查開始当初, マンガン団塊は起伏のない比較的平坦な海 底に分布していると考えられてきたが, 地形調查を進めるにつ れ, その分布域は必ずしも平坦でないことが判明した。例えば西 鉱区においては, ほぼ南北方向に発達する尾根一谷状地形 ( 比高 $200 \mathrm{~m})$ が多数みられ, 地形図上では幅数 $\mathrm{km} \sim 10 \mathrm{~km}$ 程度の縞模 様として認められる(Fig. 3a)。

特定海域における調査から, マンガン団塊の分布密度が地形的 特徵とともに数 $100 \mathrm{~m} \sim 1 \mathrm{~km}$ のオーダーで変動している可能性が 示唆されたが, 有望海域における平均サンプリング間隔は $10 \mathrm{~km}$ のオーダーであり $(5.3 \mathrm{~nm})$, より正確な資源量を求めるにはまだ 
Table 2 Statistical data of chemical compositions of manganese nodule in High Abundance Area.

\begin{tabular}{|c|c|c|c|}
\hline \multirow{2}{*}{$\begin{array}{l}\text { manganese } \\
\text { nodule data }\end{array}$} & \multicolumn{3}{|c|}{$\begin{array}{l}\text { DORD survey data in } \\
\text { High Abundance Area } \\
\text { (1979 1988) }\end{array}$} \\
\hline & $\begin{array}{l}\mathrm{Ni} \\
{[\%]}\end{array}$ & $\begin{array}{l}\mathrm{Cu} \\
{[\%]}\end{array}$ & $\begin{array}{l}\text { Co } \\
{[\%]}\end{array}$ \\
\hline Number & 202 & 202 & 202 \\
\hline minimum & 0.72 & 0.42 & 0.09 \\
\hline maximum & 1.61 & 1.30 & 0.37 \\
\hline average & 1.36 & 1.02 & 0.24 \\
\hline S.D. & 0.12 & 0.14 & 0.03 \\
\hline S.D./average & 0.09 & 0.14 & 0.14 \\
\hline
\end{tabular}

Table 3 Chemical compositions of manganese nodules in Central Pacific Basin, Clarion-Clipperton Fracture zone and High Abundance Area.

\begin{tabular}{|c|c|c|c|c|c|}
\hline \multirow{3}{*}{$\begin{array}{l}\text { Region } \\
\text { Morphological type } \\
\text { Origin }\end{array}$} & \multicolumn{3}{|c|}{ Central Pacific Basin* } & \multirow{3}{*}{$\begin{array}{c}\mathrm{CCZ}^{* *} \\
- \\
-\end{array}$} & \multirow{3}{*}{$\begin{array}{c}H A A^{* * *} \\
- \\
-\end{array}$} \\
\hline & hydrogeneous & mixture & diagenetic & & \\
\hline & smooth & intermediate & rough & & \\
\hline Number of analysis & 314 & 35 & 86 & 308 & 201 \\
\hline \multicolumn{6}{|l|}{ Elements (ave.) } \\
\hline $\mathrm{Ni}[\%]$ & 0.56 & 1.10 & 1.39 & 1.21 & 1.36 \\
\hline $\mathrm{Cu}[\%]$ & 0.38 & 0.99 & 1.32 & 1.00 & 1.02 \\
\hline Co [\%] & 0.32 & 0.20 & 0.14 & 0.26 & 0.24 \\
\hline $\mathrm{Mn}[\%]$ & 19.3 & 25.5 & 27.5 & 26.2 & 28.21 \\
\hline $\mathrm{Fe}[\%]$ & 14.5 & 10.3 & 6.6 & 6.6 & 6.65 \\
\hline $\mathrm{Mn} / \mathrm{Fe}$ & 1.48 & 2.62 & 4.63 & 3.97 & 4.24 \\
\hline $\mathrm{Ni}+\mathrm{Cu}+\mathrm{Co}[\%]$ & 1.26 & 2.29 & 2.85 & 2.47 & 2.62 \\
\hline
\end{tabular}

*data from Usui and Moritani (1992).

**data from Halbach et al. (1988)

${ }^{* * *}$ DORD survey data (1979-1988) in High Abundance Area

Table 4 The aims, methods and results of 2011 and 2012 survey cruises.

\begin{tabular}{|c|c|c|}
\hline 分類 & 目的 & 2011-2012年の調査実績 \\
\hline 地形(音響)調査 & $\begin{array}{l}\text { 採鉱可能領域の把握や資源量の推定のため、地形等に関す } \\
\text { るデータを取得する }\end{array}$ & 11測線 (176.2 nm) \\
\hline $\begin{array}{l}\text { 地質調查 } \\
\text { (海底観察) }\end{array}$ & $\begin{array}{l}\text { マンガン団塊の分布状況を把握し、地形と分布密度の関係に } \\
\text { 関するデータ等を取得する(数〜数 } 10 \mathrm{~m} \text { 間隔の写真撮影) }\end{array}$ & $\begin{array}{l}\text { 3測線 }(22.7 \mathrm{~nm}) \\
\text { 2測線 }(14.6 \mathrm{~nm})\end{array}$ \\
\hline $\begin{array}{l}\text { 地質調査 } \\
\text { (サンフリング) }\end{array}$ & $\begin{array}{l}\text { マンガン団塊·底質物の産状·品位·物性に関する基礎情報 } \\
\text { を取得する(特に地形データとの関を連を把握する) }\end{array}$ & SC 9点、LC 2点 \\
\hline 環境調査 & $\begin{array}{l}\text { JET海域の環境影響評価および高密度分布域におけるべー } \\
\text { スライン調直等を行う }\end{array}$ & 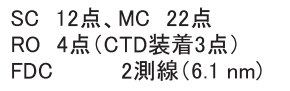 \\
\hline その他 & 製錬実験用試料の採取 & MD or AD 11回 \\
\hline
\end{tabular}

粗いと言える7)。サンプリングだけで広い範囲における分布密 度の周期変動を調查するのは膨大な数が必要となり現実的ではな いため海底観察や音響調査による方法を活用寸る必要がある。

一方, 品位についての地域差は分布密度ほどは大きくない。後 述する 2011 年以降の調查地域 (現在準精查を行っている高密度 分布域) では過年度調査 (1996 年度まで) で 202 点のサンプリン グを実施しており，その品位の統計量を Table 2 に示す。Table 2 をみると基本的には変動係数は小さく地域間変動は小さい。しか し地形的特徵と品位との関係など, よくわかっていないことも多 い。さらに GPS を導入する 1986 年以前のデータは位置精度が落 ちるため, データの十分な吟味とより位置精度の高いサンプリン グも必要であると考えられる。

なお, 品位の值は典型的な CCZの值と近く, Usui and Moritani ${ }^{15)}$ の分類に従うと mixture 〜 rough タイプに属する (Table $3^{15,16)}$ )。マンガン団塊の化学的特徵は海底近傍の酸化還 元環境や堆積物の堆積速度など海洋環境に影響されることが知ら れているが 11), この海域のマンガン団塊は粒径によって品位に 差があり，複雑な環境履歴を経ていることが予想される。

\section{3. $2011 \cdot 2012$ 年の探査航海}

\section{$3 \cdot 1$ 調査地域}

1996 年までに行った探查航海は, 調査内容からして基本的に
概査段階である。今後 $\mathrm{F} / \mathrm{S}$ 等を実施して採掘の可能性を検討する ためには, 操業開始後最初に開発が行われる地域を選定し, より 精度の高い調査を実施する必要がある。従って 2011 年以降は西 鉱区北西部の高密度分布域を対象に調查することとした。高密 度分布域は, 緯度 $10^{\circ} 15 \sim 50^{\prime} \mathrm{N}$, 経度 $148^{\circ} 20^{\prime} \sim 149^{\circ} 10^{\prime} \mathrm{W}$ の枠 (Fig. 3a の北西部の枠) に囲まれた, 約 $5,900 \mathrm{~km}^{2}$ の DORD 鉱区 を指す。この $5,900 \mathrm{~km}^{2}$ という数字は, 仮に 1 日 $1 \mathrm{~km}^{2}\left(10 \mathrm{~kg} / \mathrm{m}^{2}\right.$ で 1 万t/日), 年間 300 日操業することを想定すると, 約 20 年 操業できる面積であると計算される。高密度分布域の水深は概ね $5,100 \mathrm{~m}$ から $5,500 \mathrm{~m}$ の範囲で, 中央部 $\left(148^{\circ} 30^{\prime} \mathrm{W} \sim 149^{\circ} 0^{\prime} \mathrm{W}\right)$ は水深 $5,150 \sim 5,250 \mathrm{~m}$ 程度の高まりをなし, その東西両側は南 北方向に走る谷や尾根が分布する (Fig. 3a)。過年度の調査の結 果, この海域はマンガン団塊の分布密度が高いことが判明して おり, 概ね $10 \mathrm{~kg} / \mathrm{m}^{2}$ 以上で, 前述の中央部の地形的高まりには $15 \mathrm{~kg} / \mathrm{m}^{2}$ 以上の地帯も存在する (Fig. 3b)。鉱区全体の平均分布密 度が $8 \mathrm{~kg} / \mathrm{m}^{2}$ 程度であり ${ }^{7)}$, 西鉱区の分布密度は高密度分布域を 除くと $5 \sim 10 \mathrm{~kg} / \mathrm{m}^{2}$ が主体をなすため同地域が高い分布密度を 示すことがわかる。

\section{$3 \cdot 2$ 調査概要}

2011 年と 2012 年の 2 力年で実施した調査結果の概要を Table 4 に, 高密度分布域における資源調查の調查実績位置図を Fig. 4 に, 使用した調查機器写真を Fig. 5 に示す。 

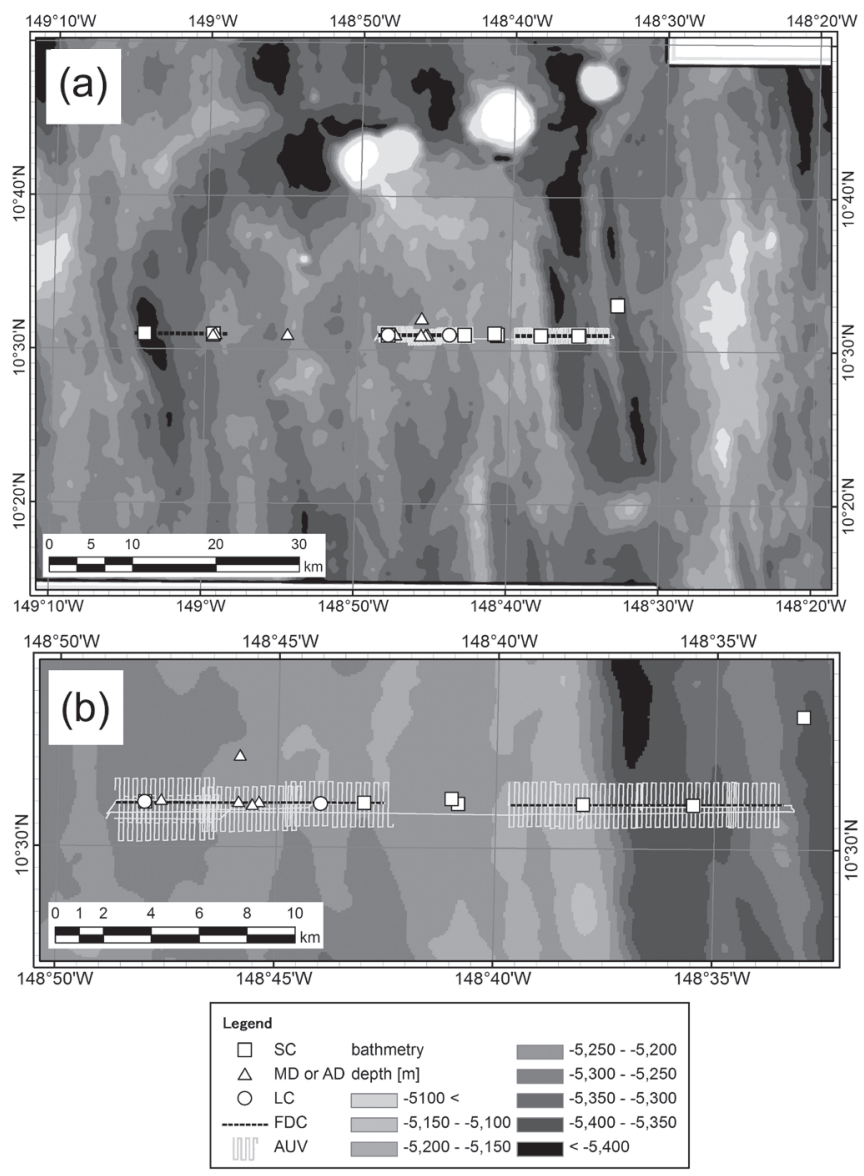
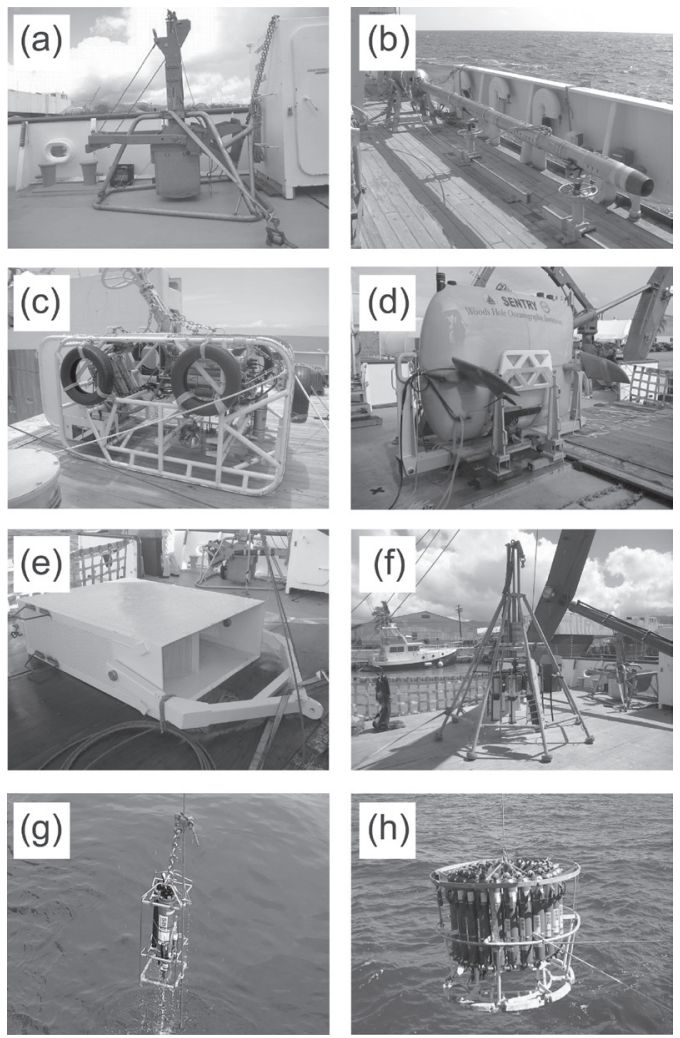

Fig.5 Survey instruments used in 2011 and 2012 surveys. (a) SC, (b) LC, (c) FDC, (d) AUV, (e) MD, (f) MC, (g) CTD and (h) RO
Fig.4 (a) Sampling locations, FDC lines and AUV tracks conducted in 2011 and 2012 survey cruises in High Abundance Area. The area demarcated by the rectangle in (a) is enlarged in (b)

2011 年 $10-12$ 月, 第 2 白嶺丸にて 35 日間の調査を実施した。 予定した曳航式 SSS 調査は海象不良により実施できず, FDCに よる海底観察を 3 測線, SC7 地点および LC2 地点のサンプリン グを実施し, 高密度分布域の中央部におけるマンガン団塊の分布 状況の確認を行った。また製錬試験に供するためドレッジを実施 し $200 \mathrm{~kg}$ のマンガン団塊を採取した。環境調査ではJET 海域に おいて, 海底かく乱実験 (1994 年に実施) 後の環境影響を把握・ 評価するため, FDC 海底観察とサンプリングを行った。

2012 年は長年使用した第 2 白嶺丸が廃船になったことを受け, 八ワイ大学所有の R/V Ka' imikai-O-Kanaloa (KOK) をチャーター して調查を実施した。2012 年の調査は 8 月 - 9 月の Leg1 (31 日 間 ), 9 月 - 10 月の Leg2 (23 日間) からなる。 Leg1 ではサンプ リング調查 (SC2 地点, 環境調査も実施), Leg2 では AUVによ る地形調查と海底写真撮影を実施した。AUV はウッズホール海 洋研究所所有の “Sentry”を使用した。

\section{$3 \cdot 3$ 調査結果}

(1) 地形調査 ウッズホール海洋研究所の “Sentry” は最 大 $6,000 \mathrm{~m}$ 水深まで潜行可能な AUVである (詳細な仕様は同 研究所のホームページを参照のこと; https://www.whoi.edu/)。 $\mathrm{MBES} \cdot \mathrm{SSS} \cdot \mathrm{SBP} \cdot \mathrm{CTD} \cdot$ 深海カメラなど多数の調査機器の取り付 けが可能で, 海底面及び海底面付近の多様な情報が取得できる。 本航海の AUV 調查は潜航 16 時間前後 (潜航距離 $40 \mathrm{~km}$ 程度), 揚収後のデータ吸い取りと充電等で 20 時間前後, 合計 $35-40$ 時間のサイクルで行った。AUVは計 11 回潜航し, 総長 $326 \mathrm{~km}$ の距離で地形データを取得した。地形調查範囲は Fig. 4 に示さ

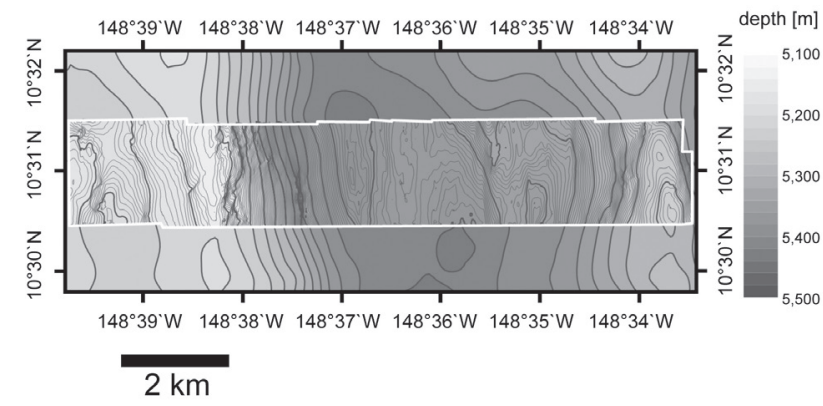

Fig.6 Bathymetric map of a part of High Abundance Area located in the northwest of West Area of Japanese license area. Detail map with 2 $\mathrm{m}$ contour lines obtained from 2012 cruise (within a white frame in the figure) is overlaid on map with $20 \mathrm{~m}$ contour lines obtained from 1990 's MBES data.

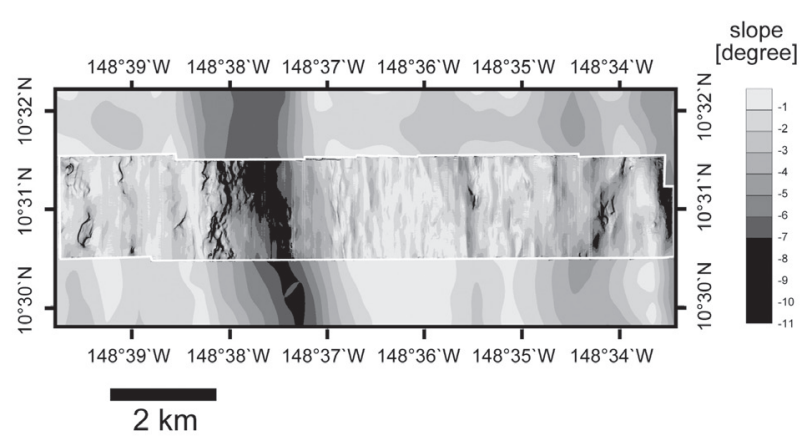

Fig.7 Gradient distribution map of a part of the High Abundance Area. Map depicted from 2012 AUV data is overlaid on one depicted from 1990's MBES data. 


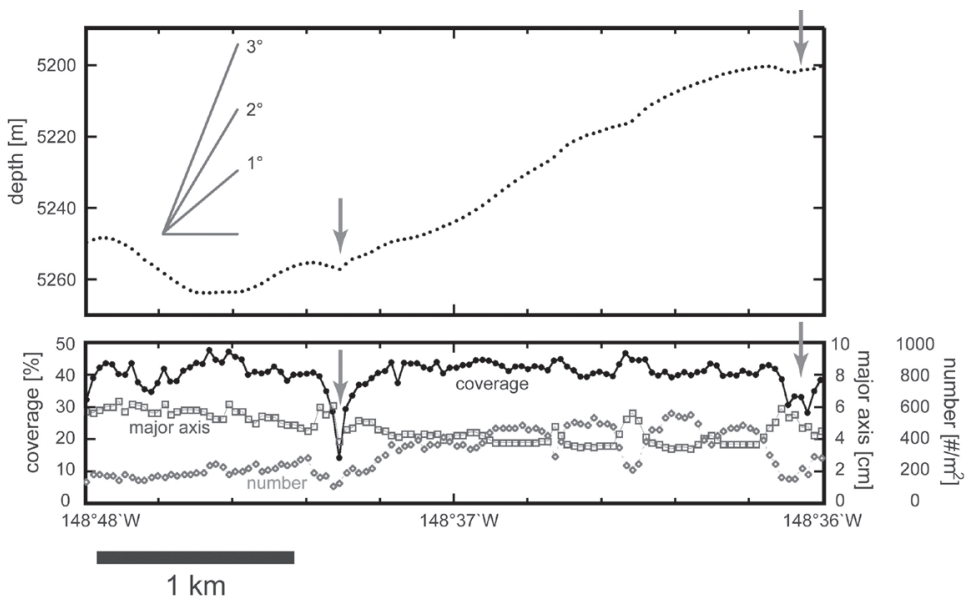

Fig.8 Example of features of manganese nodules distribution obtained from image processing of seafloor photographs taken by AUV camera.

れるように, 2011 年度に実施した FDC 測線を含むように設定さ れ, 約 $10 \mathrm{~km} \times 2 \sim 3 \mathrm{~km}$ の 2 の領域 (西部約 $24 \mathrm{~km}^{2}$, 東部約 $21 \mathrm{~km}^{2}$ ) である。Fig. 6 に AUV 調査で取得したデータから作成し た等深線間隔が $2 \mathrm{~m}$ の海底地形図を, Fig. 7 に傾斜分布図を示す。 Fig. 6, Fig. 7 のそれぞれの上部には，1996 年以前に第 2 白嶺丸 のMBES 調査で取得したデータで作成した図面 ( 等深線間隔が $20 \mathrm{~m}$ の海底地形図, 傾斜分布図) を載せている。これらの図面デー タから，採鉱可能領域の把握や資源量の推定を行った。

（2）地質調査 (サンプリング ) 2011 年以降の資源量調査の ためのサンプリングは, 採取効率等の観点から FG は使用せず, SC, LC のみで対応し, 原則 1 測点 1 回行うこととした。そして 2011 ・2012 年の両年で SC, LC それぞれ 9 点, 2 点のサンプリン グを実施した（Table 4)。サンプリング後の試料に対しては，従 来行っている方法と同様の処理を行った。ただし品位分析や密度 測定などの室内試験のほとんどは陸上に試料を持ち帰った後, 専 門の業者に依頼した。今後もサンプリングデータのコンパイルを 行い, AUVで取得した地形データとマンガン団塊の分布状況に ついて考察を進める予定である。

（3）地質調査（海底観察）ＦDC およびAUVの観察測線は, 高密度分布域を東西に横断するように設定した。Fig. 4 に示すよう に, FDC は 3 測線 (合計 $42 \mathrm{~km}$ ), AUV は 2 測線 (合計約 $27 \mathrm{~km}$ ) 実施し, AUV2 測線は FDC 測線と平行になるよう東西方向に設 定した。AUV の計画測線を FDC 測線と平行に設定したのは1) AUV 測線と FDC 測線に囲まれた, 極狭い領域の正確な資源量を 算出し, 従来の推測資源量との差を比較するため, また2) 東西 方向の地形変化 ( 当海域は南北方向に延びた谷〜尾根地形が繰り 返す地形) に伴い分布密度も変化している状況を正確に把握する ためである。

FDC や AUV で撮影した海底静止画像 (デジタル画像) に対し ては, 陸上に持ち帰った後マンガン団塊の面積率・長径・個数 データを取得するため画像解析を行った。解析対象は, FDCで は約 $30 \mathrm{~m}$ 間隔で撮影した画像で, AUV では約 3.3 秒毎 (約 $2.4 \mathrm{~m}$ 毎) に撮影したが，FDCデータと同様 $30 \mathrm{~m}$ 間隔で (12 枚おきに) 抽出した画像である。東西方向のトレンドを知るために解析した 画像枚数は FDC は 1,115 枚, AUV は合計 906 枚である。なお, FDC で得られた海底静止画像 (30m 間隔) と AUVで得られた海 底静止画像 (約 $2.4 \mathrm{~m}$ 間隔) の解析結果を比較すると両者のマン ガン団塊の面積率・長径・個数の変動の様子は極めて類似してお り, 変動のスケールは一般に $30 \mathrm{~m}$ より大きい。従って AUV デー
Table 5 Statistical data of features of manganese nodule distribution obtained from image processing of seafloor photographs taken by AUV camera.

\begin{tabular}{|c|c|c|c|c|c|}
\hline \multirow[t]{2}{*}{$\begin{array}{l}\text { manganese } \\
\text { nodule data }\end{array}$} & \multicolumn{4}{|c|}{$\begin{array}{c}\text { imageprocessing data of seafloor } \\
\text { photographs obtained from } 2012 \text { AUV } \\
\text { survey. }\end{array}$} & \multirow{2}{*}{$\begin{array}{l}\text { estimated } \\
\text { abundance } \\
{\left[\mathrm{kg} / \mathrm{m}^{2}\right]}\end{array}$} \\
\hline & $\begin{array}{l}\text { depth } \\
{[\mathrm{m}]}\end{array}$ & $\begin{array}{c}\text { coverage } \\
{[\%]}\end{array}$ & $\begin{array}{c}\text { long axis } \\
{[\mathrm{cm}]}\end{array}$ & $\begin{array}{c}\text { number } \\
\left\lceil \# / \mathrm{m}^{2}\right\rceil\end{array}$ & \\
\hline Number & 906 & 905 & 905 & 905 & 905 \\
\hline minimum & 5140 & 0.9 & 2.49 & 17.5 & 0.4 \\
\hline maximum & 5382 & 47.8 & 7.63 & 996.2 & 21.9 \\
\hline average & 5245 & 34.2 & 4.23 & 370.5 & 11.4 \\
\hline S.D. & 63 & 10.9 & 0.98 & 218.0 & 3.7 \\
\hline S.D./average & 0.01 & 0.32 & 0.23 & 0.59 & 0.32 \\
\hline
\end{tabular}

夕を $30 \mathrm{~m}$ 間隔で抽出したことに問題はないと考えられる。

画像処理・解析には市販のソフトウェアを使用し, ソフトウェ アの自動処理とマニュアル操作を組み合わせながらマンガン団塊 の被覆面積や平均粒径, 単位面積当たりの個数を求めた。具体的 には適当な閾值を用いてマンガン団塊 (暗色) と海底堆積物 (明 色) を2 值化し, マンガン団塊を自動抽出した後, 最後に手動で 誤認識等を修正した。画像解析により求めた面積率等のデータを, 経験式に代入することにより画像毎の分布密度の推定值を計算し た。なお, 上記のような, 画像処理の手動で行う部分を減らし, PC ソフトウェアによる完全自動化を目指すことは今後の課題の 1 つである。

Fig. 8 は AUV の撮影画像の解析から求められた粒径, $1 \mathrm{~m}^{2}$ 当 たりの個数 (以下, 個数), 面積率, ならびにこれらのデータか ら求められた推定分布密度を, 緯度 (横軸) に対してプロットし た図である。また Table 5 にはこれらのパラメータに対する統計 量を示す。マンガン団塊の平均粒径 (長径) は $4 \sim 6 \mathrm{~cm}, 1 \mathrm{~m}^{2}$ 当 たりのマンガン団塊の個数は $200 \sim 600$ 個で推移している。粒 径と個数は逆相関の関係にあり, これらの積で求められる面積 率は約 $40 \%$ 程度で概文安定しているようである。しかし, Fig. 8 の矢印部分でみられるように地形的に局所的な凹地で面積率が 急激に下がっているようなところもある。また, 分布密度につ いても Table 5 に示すように平均は $11.4 \mathrm{~kg} / \mathrm{m}^{2}$ で, $\pm 2 \sigma$ では 4 $18.8 \mathrm{~kg} / \mathrm{m}^{2}$ と大変ばらつきがある。面積率 (または分布密度) が 急激に下がる場所は傾斜が $5^{\circ}$ 以上の地帯が広く分布し, 底質物 下層の古期堆積物の露出している様子が確認されることもあり, 
Table 6 Status of contracts for exploration for manganese nodule.

\begin{tabular}{|c|c|c|}
\hline 国* $^{*}$ & 探査契約 & 申請者 \\
\hline IOM & 2001.3 .29 & $\begin{array}{l}\text { Interoceanmetal Joint Organization } \\
\text { (ブルガリア、チェコ、スロバキア、ポーランド、ロシア、キューバ) }\end{array}$ \\
\hline ロシア & 2001.3 .29 & Yuzhmorgeologiya \\
\hline 韓国 & 2001.4 .27 & The Government of the Republic of Korea \\
\hline 中国 & 2001.5.22 & $\begin{array}{l}\text { The China Ocean Mineral Resources Research and } \\
\text { Development Association }\end{array}$ \\
\hline フランス & 2001.6 .20 & IFREMER AFERNOD \\
\hline 日本 & 2001.6 .20 & Deep Ocean Resources Development Co., Ltd. \\
\hline インド** & 2002.3.25 & The Government of India \\
\hline ドイツ & 2006.7.19 & $\begin{array}{l}\text { The Federal Institute for Geosciences and Natural Resources } \\
\text { of the Federal Republic of Germany }\end{array}$ \\
\hline ナウル & 2011.7 .22 & Nauru Ocean Resources Inc. \\
\hline トンガ & 2012.1.11 & Tonga Offshore Mining Ltd. \\
\hline ベルギー & 2013.1 .14 & G-Tec Sea Minerals Resources NV, \\
\hline イギリス & 2012年申請 & UK Seabed Resources Ltd. \\
\hline キリバス & 2012年申請 & Marawa Research and Exploration Ltd. \\
\hline シンガポール & 2013年申請 & Ocean Mineral Singapore Pte. Ltd. \\
\hline
\end{tabular}

この傾向が調查海域でどの程度一般的であるのか, さらに調べる 必要がある。

画像処理の結果をもとに, AUV·FDC 両測線に囲まれた極狭い 範囲における，より正確な資源量の推定を試みているが，幾つか 課題が残されており，今後も引き続き検討する予定である。

\section{4. 今後の航海計画について}

現在 DORD は ISA との探査契約を締結しており, 探査航海や 環境航海, その他の事業について取りまとめ毎年, 年次報告書を 提出寸る義務があるが，その報告書は ISA の法律技術委員会义 ンバーに閲覧され，評価や提言を受けている。そのなかには今 後の航海の調查内容について言及しているものもある。例えば 2001 年に採択された環境ガイドラインを通じて, 環境影響評価 を行うための環境データの取得を強く推奨している。このような 提言に対して適切に対応するため, 2013 年の航海では, 引き続 き環境ベースラインデータの取得の他に, 推奨項目として挙げら れている ADCP 係留系を投入する計画を立てている。マンガン 団塊の航海は探査データの取得および上記のような環境調査のた めに実施しているが, 航海日数には限りがあるため, 探查・環境 それぞれの優先順位や必要調查項目を考慮した上で効率的な航海 計画を立てる必要がある。

その他, 探査契約を締結している諸外国の動向や最新の探査技 術等の情報収集も航海計画の立案と無関係ではない。2013 年 3 月現在, マンガン団塊に関してISA と探查契約を締結している国・ 機関は 11 あり, Table 6 に示すように, ここ 2 年でナウル・トンガ・ ベルギーが契約し，2013 年 5 月現在もイギリス・キリバス・シ ンガポールが申請中で飛躍的に数が増えている。また, 調查開始
当初日本は先行投資者として技術開発の面で国際的に優位にあっ たものの，近年は逆に諸外国での採鉱システムの開発等の活動が 活発化している ${ }^{5)}$ 。採鉱システムのタイプによっては収集すべ き (重要度の高い) 地質データの内容も変わる可能性もあるため, 諸外国の動向を把握することが重要になる。また，探査技術につ いても近年大きく進歩し, AUV 調査のように今後の詳細な地形・ 地質データ取得においては高度な機器・技術の導入は不可欠であ るため, 継続的に ISA の主催する会議や学術会議等に参加し情 報収集することが必要である。

なお AUV 調査でカバーできる調査範囲は現状では 1 航海当た り $50 \mathrm{~km}^{2}$ 程度であり, 現在の方法をそのまま踏襲し, 数 10 年か けて鉱区全体の詳細な地形データを取得するのは現実的ではな い。そのため高密度分布域 (あるいは, その他のモデル地区) で データを取得し, そのデータから得られた知見を他の地域に適用 していくことが必要となり, 適切に調查地域を選定することが大 変重要になる。

謝辞本調査は, 経済産業省の委託を受けた JOGMEC の調 査の一環として実施された。経済産業省並びに本業務に携わった 関係各位に感謝の意を表します。

本稿で述べたマンガン団塊の探査航海は旧通商産業省 ( 現経済 産業省）資源エネルギー庁からの委託事業で旧金属鉱業事業団 ( 現独立行政法人石油天然ガス・金属釷物資源機構) が深海資源 開発株式会社に再委託したものであり，本稿で使用した文章や表 の一部は，下記の引用文献リストからは省略するが，1997 年に 旧金属鉱業事業団・深海資源開発株式会社が取りまとめたマンガ ン団塊総括報告書及び 2011 年・ 2012 年の委託調査の年次報告書 から引用している。本文中で述べた課題等の見解については個人 的なものが含まれていることをおことわりしておきたい。

\section{References}

1) Y. Shiga: Shigen Chishitsu, 51 (2001), 41-53.

2) A. Inokuma, H. Okada, and T. Oyama: Journal of MMIJ, 112 (1996), 974-983.

3) K. Kojima: Journal of MMIJ, 112 (1996), 968-973.

4) H. Moriwaki: Journal of MMIJ, 112 (1996) , 1021-1025.

5) T. Yamazaki: Kinzokushigen report, 36 (2007) , 970-981.

6) K. Matsumoto, N. Murayama and K. Matsui: kinzokushigen report, 36 (2006) , 692-713.

7) A. Tsune and M. Okazaki: 23nd Ocean Engneering Symposium, (Nihon University), OES23-92, (2012) .

8) T. Moritani: Journal of geography (Chigaku Zasshi), 87 (1978) , 1-20

9) K. Matsumoto: Chishitsu News. 550 (2000), 13-17.

10) T. Moritani: Journal of geography (Chigaku Zasshi), $\mathbf{5 5 0}$ (2000), 18-23.

11) 白井朗: 海底鉱物資源一未利用レアメタルの探査と開発, (オーム社, 2010), pp.200。

12) International Seabed Authority: A geological model of polymetallic nodule deposits in the Clarion Clipperton fracture zone, ISA Technical Study No.6 (international Seabed Authority, 2012) .

13) A. Mizuno, J. Chujo and E. Inoue: Chigaku News, 238 (1974) , 1-12.

14) J. Chujo, T. Ishihara and F. Murakami: Bulletin of the Geological Survey of Japan, 28 (1976), 69-102.

15) A. Usui and T. Moritani: Geology and offshore mineral resources of the central Pacific Basin 14, (ed. Keating Bolton; Springer, 1992), pp. 205-223.

16) P. Halbach and D. Puteanus: Geochemical trends of different genetic types of nodules and crusts. In The manganese nodule belt of the Pacific ocean (ed. P. Halbach, G. Friedrich, and U. Von Stackelberg), pp. 61-69. 